"Stronger US-India strategic ties resulting from the pact would lessen India's need to greatly expand its nuclear arsenal and would bind Indian governments more firmly to norms against nuclear testing."

\title{
The US-India Nuclear Pact: A Good Deal
}

\author{
DinSHAW MisTRY AND SUMIT GANGULY
}

$\mathrm{T}$ he civilian nuclear cooperation deal between India and the United States, struck in July 2005 by President George W. Bush and Indian Prime Minister Manmohan Singh, constitutes a major initiative for both nations. President Bush seeks pathbreaking exemptions in US law and international nuclear regime guidelines to allow for nuclear energy transfers to India. In return, India has agreed to separate its civilian and military nuclear facilities and put the civilian component under international safeguards.

Specifically, India would place 14 of its 22 thermal power reactors in operation or under construction, representing 65 percent of its nuclear power capacity, under permanent international safeguards. It would keep its breeder reactor outside the safeguards. And it would shut down one of its two dedicated military-related reactors that produce weapons-grade plutonium. New Delhi also has agreed to maintain its self-imposed moratorium on nuclear testing, support talks on the Fissile Material Cutoff Treaty, and adhere to international guidelines on nuclear and missile export controls.

This agreement is intended to strengthen Washington's strategic partnership with India, and thereby to advance key us objectives, such as promoting a stable power balance in Asia. Yet critics contend that the deal could unravel the carefully woven fabric of the nuclear nonproliferation regime. We affirm that the nuclear deal with India is likely to result in strategic gains for Washington, and it could also bring energy, economic, and environmental benefits.

DINSHAW MISTRY is an associate professor of political science at the University of Cincinnati and author of Containing Missile Proliferation (University of Washington Press, 2005). SUMIT GANGULY, a Current History contributing editor, is a professor of political science at Indiana University. His most recent book, edited with Andrew Scobell and Brian Shoup, is US-India Strategic Cooperation into the Twenty-First Century: More Than Words (London: Routledge, 2006).
The agreement's effect on the nonproliferation regime would be mixed. It might undermine an important nonproliferation norm on nuclear energy transfers. However, this negative impact can be reduced by appropriately framing the exemption for India. And the accord could bring proliferation benefits. Stronger US-India strategic ties resulting from the pact would lessen India's need to greatly expand its nuclear arsenal and would bind Indian governments more firmly to norms against nuclear testing. Ultimately, in the absence of a nuclear agreement, the strategic gains would be forfeited and, while the proliferation concerns would not arise, the proliferation benefits would also not materialize. Thus, the overall benefits of the agreement outweigh those that would flow from not implementing it.

\section{STRATEGIC GAINS}

In the past few years, military, economic, and political ties between the United States and India have dramatically expanded. The two countries have conducted a series of military exercises involving all three branches of their armed forces; there is growing, if fitful, intelligence sharing between the two nations; and India may well purchase substantial quantities of Us military equipment in the foreseeable future. An expanding economic partnership, in turn, undergirds the strategic relationship. For example, some 220 American Fortune 500 companies have significant investments in India. As a consequence of these profound changes, Washington now sees New Delhi as a potential strategic partner. By removing barriers to technology cooperation with India in the nuclear area, the nuclear agreement is intended to lay the foundations for greater strategic cooperation. As we have written in the summer issue of World Policy Journal, such cooperation with India would advance US security objectives in Asia and beyond. 
First, a stronger partnership with New Delhi would help Washington balance a rising China. There is little question that American policy makers harbor misgivings about the dramatic growth of Chinese economic and military power. And, while New Delhi's relations with Beijing have improved substantially in recent years, India retains some anxieties about a resurgent and possibly revanchist China. Although Washington cannot realistically expect to use Indian military bases in the event of a conflict with China, it can reasonably expect India to share critical intelligence about Chinese military capabilities, especially in the Indian Ocean and its littoral states. Given the significance of the region to India's maritime interests, the growing Chinese presence in Burma has generated considerable misgivings in Indian military circles.

Second, a viable strategic partnership with India could bring military and political benefits for Washington. In the aftermath of the 9-11 attacks, Indian naval vessels helped patrol areas in the Indian Ocean littoral in concert with the US Navy. More recently, in the aftermath of the 2004 Asian tsunami, India coordinated relief efforts with the US Navy from Sri Lanka to Indonesia. These two ventures were made possible because the two navies had developed prior habits of cooperation through a series of naval exercises. Likewise, the US and Indian air forces have conducted mock hostile exercises, and Indian and American ground troops have held joint exercises in terrain ranging from the tropical jungles of India's northeast to the frozen wastes of Alaska.

India has started to work in concert with the United States on international security issues that extend well beyond South Asia. After considerable deliberation, for example, India chose to align itself with the United States on referring Iran to the UN Security Council in September 2005 and again in February 2006. New Delhi would not have aligned with Washington had a nuclear cooperation agreement not been under consideration at the time.

Overall, under a stronger strategic relationship, the scale of US-India military cooperation, security and foreign policy coordination, intelligence sharing, and arms sales could all increase. In the past few years, these activities have proceeded apace despite a change in government in India from the conservative Bharatiya Janata Party-led coalition to a more left-of-center Congress Party administration.

On the other hand, if the nuclear agreement fails to materialize, the substantial improvement that has taken place in US-India relations over the past decade will suffer a significant setback. Many of the strategic initiatives under way could face reconsideration. Key individuals and groups within the Indian political arena who are virulently opposed to the improvement of US-India ties would exploit the failure to realize the nuclear deal as evidence of American perfidy and the ruling Indian government's ineptitude and naiveté. Consequently, the strategic significance of the nuclear agreement for advancing US-India bilateral relations cannot be overstated.

Even with a nuclear pact, there are possible scenarios under which the cooperative trend in US-India strategic ties could be hobbled. If, after future elections, a coalition of left-wing political parties were to govern India, they could distance India from America and seek to scale back the dimensions of military cooperation. But the likelihood of this is generally small. Another scenario involves the resurgence of populist hostility in the United States toward India over the question of employment outsourcing. This issue had limited traction, however, during the 2004 Us elections and is now mostly a spent force. A third possibility might involve closer US alignment with Pakistan that angers India. But this will not occur if Washington is careful not to alienate New Delhi as it maintains ties with Islamabad.

\section{Proliferation CONCERNS}

The nuclear agreement with India raises two sets of proliferation concerns. The first concern is that granting India an exemption from an important nonproliferation rule would undermine the nonproliferation regime. In particular, India would be exempted from a 30-year-old policy-implemented under Us law and international Nuclear Supplier Group guidelines-that forbids the transfer of civilian nuclear technology to any country that has not acceded to the nuclear Non-Proliferation Treaty (NPT) and accepted full-scope international safeguards. A major concern, as The New York Times noted in an April 7, 2006, editorial, is that, "In trying to give India a special exemption, Mr. Bush is threatening a carrot-and-stick approach that has been effective for more than 35 years. It is the legal basis on which Secretary of State Condoleezza Rice is trying to build a coalition against Iran's nuclear program. The treaty has persuaded countries like South Korea, Japan, and Brazil to forgo nuclear weapons."

The exemption for India thus could set a worrisome precedent, one that might affect the decisions of key countries to remain in the NPT. If a nation relies significantly on nuclear energy for its 
economy, and particularly on foreign imports of reactors and fuel, then it is less likely to break out of the NPT if this disrupts its energy supplies. But if leaving the NPT would not affect a country's nuclear energy imports (because it is receiving an exemption from Nuclear Supplier Group guidelines), it may be more inclined to break out from the NPT. The effect of such a precedent may well depend on how the exemption for India is framed.

If it emphasizes that countries may only win exemption from the full-scope safeguards rule after being subject to this rule for some 20 to 30 years (as is the case with India), and only if they adhere to major nonproliferation rules, the damage to the nonproliferation regime may be limited. In this case, the carrot-and-stick NPT approach would still be affirmed, because India incurred important costs (being denied civilian nuclear imports for three decades) before receiving an exemption from this approach. Further, New Delhi only received an exemption because of its good export control record, and it would retain its exempt status only as long as it complies with nonproliferation norms such as those against nuclear testing.

A second proliferation apprehension is that the nuclear agreement would enable India to expand its nuclear program and this would cause an arms race with Pakistan and China. There is concern that foreign-supplied uranium fuel for India's civilian reactors would free up India's limited uranium supplies for use in military reactors, and this could allow a large nuclear buildup by India. Yet, in the short term, India may have only one main reactor producing weapons-grade plutonium. This is the Dhruva reactor, which produces plutonium sufficient for about five nuclear weapons annually. (India's other dedicated military reactor, the Cirus reactor, which produces plutonium for about two nuclear weapons annually, is to be shut down by 2010.) Thus, even if foreign-supplied uranium frees up some of India's uranium supplies for military reactors, India would only produce weaponsgrade plutonium for about five nuclear weapons per year from this military reactor. Although India would retain eight heavy water reactors outside international safeguards, these produce reactorgrade plutonium. While it is possible to use such plutonium in a nuclear weapon, it is not ideal for nuclear weapons. Moreover, India already has a very large stock of reactor-grade plutonium and plans to use about one-third to half of this material to fuel its first breeder reactor (similar amounts may be needed for future breeder reactors).

India's breeder reactor, which is outside safeguards, could produce refined plutonium sufficient for dozens of nuclear weapons every year. This concern will not be realized in the short term, however, because the breeder will not be operational until around 2010. A few years after it goes on line, the breeder would produce vast amounts of plutonium. But even then India may not use most of this plutonium for nuclear weapons, for a number of reasons.

First, India may soon have enough nuclear material to field a minimum deterrent. Until now, India's Dhruva and Cirus reactors have produced plutonium sufficient for 65 to 110 nuclear weapons. Experts estimate that if India has between 100 and 150 deliverable nuclear weapons, they provide a sufficient deterrent against China and Pakistan. Thus, India may not require much plutonium from the breeder for a minimum deterrent. Second, India may require breeder-derived plutonium to fuel future breeder reactors. (The plutonium derived from India's heavy water reactors may be insufficient for fueling more than two or three breeder reactors.) India's Department of Atomic Energy plans to build three additional breeders that could become operational around 2020. In this case, much of the plutonium produced from India's first breeder reactor would not be available for nuclear weapons (though some of it could be), and instead would be used to fuel future breeder reactors.

Further, as the India-US strategic relationship deepens, India is less likely to feel the need to build a substantial nuclear arsenal. Increased militaryto-military cooperation with Washington, and the possibility of reliable access to American conventional weapons, would lessen the need for India to greatly expand its nuclear weapons program. As a result, India would then be more amenable to joining the Fissile Material Cutoff Treaty, which would be a major barrier to India's accumulation of plutonium. Once this treaty is in place and India signs it, India would not be able to use future plutonium from any of its reactors for nuclear weapons.

This leads to a nonproliferation benefit of the nuclear agreement: its potential for restraining 
India's nuclear expansion and for binding India to norms against nuclear testing. Most of India's nuclear weapons are believed to be first-generation fission weapons, and India's 1998 thermonuclear test was at best a partial success. New Delhi has committed itself to a moratorium on nuclear testing under the US-India agreement. If India breaks this moratorium, it will jeopardize its ability to import nuclear reactors and fuel to meet its energy requirements. Given a stronger strategic partnership with Washington, governments in New Delhi would have less compulsion to consider-and would be loath to alienate Washington with-a resumption of nuclear tests.

\section{RECOGNIZING REALITY}

India's economy has grown at a rate of 6 to 7 percent annually in recent years. If this rate is maintained, India's demand for electricity is expected to increase considerably, perhaps by 10 percent per year. The nuclear deal would provide an important and environmentally friendly energy source for a growing Indian economy, and could also offer export opportunities for the US nuclear industry.

India's existing reactors generate around 3,310 megawatts (MW) of electricity and supply only about 3 percent of India's electricity. Reactors under construction (including two Russian-built 1,000 MW reactors) will generate an additional 3,420 $\mathrm{MW}$ by 2010. In the decade after 2010, India expects to build additional reactors that would generate perhaps 5,000 MW. This would still leave the country short of its goal of generating 20,000 MW of nuclear power (representing perhaps 7 percent of India's total electric generating capacity) by around 2020. To meet these energy targets, India could import six to ten reactors, two of which could be us light water reactors (possibly supplied by General Electric), which could result in a few thousand jobs, both directly and indirectly, for the us nuclear industry.

India's development and import of nuclear reactors will have a positive environmental impact. Analysts estimate that if India increases its nuclear generating capacity nearly tenfold, then these nuclear plants, by displacing coal-fired plants, would lessen India's carbon dioxide emissions by about 130 million tons per year. (For comparison, emission cuts planned by the European Union under the Kyoto Protocol are some 200 million tons per year.) Although these reductions represent only a small fraction of India's carbon dioxide emissions, they would still make a positive contribution to global environmental objectives.

It should be clarified that these energy, environmental, and commercial calculations are based on the assumptions that India's economy will maintain 6 to 7 percent growth rates over one to two decades, and that India will require and find it costeffective to use nuclear energy (rather than other forms of energy) to sustain this economic growth. Growth rates could fall during an economic crisis, and nuclear power with its high capital costs could prove more expensive than alternative energy sources. Thus, it is difficult to estimate the magnitude of the economic, environmental, and energy gains from the nuclear agreement with India.

But even in the absence of the nuclear deal, India would continue to seek new sources of energy to fuel and sustain its current rates of growth. In this quest for energy resources, it would invariably invest in nuclear reactors even if they failed to achieve the levels of efficiency and output characteristic of Russian, French, or American reactors. (India has mostly built $220 \mathrm{MW}$ reactors, and has only recently completed two 540 MW reactors, whereas foreign suppliers could provide larger 1,000 MW reactors.) Pursuing a strategy of technology denial has only succeeded in slowing down India's civilian and military nuclear programs. It has failed utterly to stop them.

The nuclear agreement with India is not the first civilian nuclear cooperation pact with a nuclear weapon state that is outside the NPT. In 1985, the Reagan administration reached a bilateral civilian nuclear power agreement with the People's Republic of China-which was not yet an NPT signatory. Although civilian nuclear transfers to India could undermine an important existing nonproliferation rule, the negative effects can be reduced by appropriately framing the exemption for India. Thus, if properly implemented, the nuclear agreement with India would be a good deal. It would recognize the reality of India's nuclear weapons program and address India's energy needs without undermining the nonproliferation regime, and would considerably strengthen the US-India strategic partnership. 